\title{
Diversification and Soil Management Effects on the Quality of Organic Apricots
}

\author{
Roberto Ciccoritti ${ }^{1}\left(\mathbb{D}\right.$, Roberto Ciorba ${ }^{1}$, Francesco Mitrano ${ }^{1}$, Marcello Cutuli ${ }^{1}$, Tiziana Amoriello ${ }^{2}($, \\ Corrado Ciaccia $^{3}{ }^{-1}$, Elena Testani ${ }^{3}\left({ }^{-1}\right.$ and Danilo Ceccarelli ${ }^{1, *}$
}

1 CREA Research Centre for Olive, Fruit and Citrus Crops, Via di Fioranello 52, 00134 Rome, Italy; roberto.ciccoritti@crea.gov.it (R.C.); roberto.ciorba@crea.gov.it (R.C.); francesco.mitrano91@gmail.com (F.M.); marcello.cutuli@crea.gov.it (M.C.)

2 CREA Research Centre for Food and Nutrition, Via Ardeatina 546, 00178 Rome, Italy; tiziana.amoriello@crea.gov.it

3 CREA Research Centre for Agriculture and Environment, Via della Navicella, 4, 00184 Rome, Italy; corrado.ciaccia@crea.gov.it (C.C.); elena.testani@crea.gov.it (E.T.)

* Correspondence: danilo.ceccarelli@crea.gov.it; Tel.: +39-067-934-8108; Fax: +39-067-934-8187

check for updates

Citation: Ciccoritti, R.; Ciorba, R.; Mitrano, F.; Cutuli, M.; Amoriello, T.; Ciaccia, C.; Testani, E.; Ceccarelli, D. Diversification and Soil Management Effects on the Quality of Organic Apricots. Agronomy 2021, 11, 1791. https://doi.org/10.3390/ agronomy11091791

Academic Editors: Laura Siracusa and Rosa Palmeri

Received: 29 July 2021

Accepted: 4 September 2021

Published: 7 September 2021

Publisher's Note: MDPI stays neutral with regard to jurisdictional claims in published maps and institutional affiliations.

Copyright: (c) 2021 by the authors. Licensee MDPI, Basel, Switzerland. This article is an open access article distributed under the terms and conditions of the Creative Commons Attribution (CC BY) license (https:// creativecommons.org/licenses/by/ $4.0 /)$

\begin{abstract}
Nutritional and commercial value of the apricot fruits depends on the interaction among several factors, including the management strategies, the environmental conditions, and the genotype. This study aimed to evaluate the effect of orchard management and pedoclimatic conditions on apricot fruit quality traits (soluble solids, titratable acidity, dry matter and soluble solids and titratable acidity ratio) and phytochemical content (total phenolic content and antioxidant activity). Two apricot cultivars (Kioto* and Pieve*) were subjected to three different organic systems: (i) a standard management (BAU), (ii) an innovative diversified system with reduced tillage based on the natural cover conservation (INC) and (iii) an innovative diversified system with introduction of different cover crops (ICC), for two consecutive years (2019-2020). Overall, besides the effect of the climatic conditions, the multivariate analysis revealed the role of management systems, rather than genotype, on the quality of apricot fruits. In particular, INC soil management positively affected soluble solids, titratable acidity and dry matter parameters, especially in environments with low

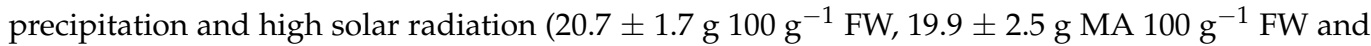

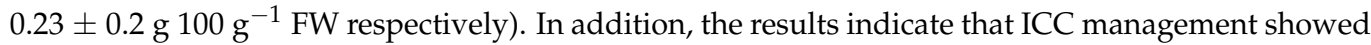
the highest antioxidant values (1.45 $\pm 0.19 \mu \mathrm{g}$ of Trolox equivalent (TE) $\left.100 \mathrm{mg}^{-1} \mathrm{FW}\right)$, especially in the environment with high precipitation. This study was a useful tool for farmer to choose an effective organic system management in order to obtain fruits with high quality parameters.
\end{abstract}

Keywords: chemical and physical traits; antioxidants; organic management; generalized linear models; postharvest quality

\section{Introduction}

Apricot (Prunus armeniaca L.) is a fruit species widely spread in the temperate zones of the world, whose fruits are highly appreciated for their characteristic flavor, sweetness and juiciness. Italy is the fourth world's apricot producer after Turkey, Uzbekistan and Iran, and it is a leading country in Europe [1]. In 2019, the Italian apricot annual production was 279,900 tons $(6.7 \%$ of the total world production) and the cultivated area covered 17,910 ha (3.1\% of the world area), of which about $14.9 \%$ were organic [1]. The increasing market demand in production and consumption of fresh and dried apricots is mainly due to the positive effects on human health and disease risk reduction [2-6]. Indeed, apricots are rich in several phytochemicals such as sugars (mainly glucose, fructose and sucrose), organic acids (mainly malic, citric and quinic acids) [7], and bioactive compounds (phenolics, flavonoids, anthocyanins, carotenoids, dietary fiber, minerals and vitamins). All these compounds coupled with the fruit's physical and chemical characteristics are responsible 
for the apricot quality. In particular, phenols strongly contribute to the antioxidative potential of the fruit, suggesting a key role in the defense system against oxidative stress in human tissues [8].

Furthermore, consumers usually assess fruits for appearance, size, sweetness (sugar composition or sugar/acid ratio) and taste [9]. In addition, farmer's choices in terms of management and cultivars are done to satisfy consumers expectations in terms of quality and, especially for organic products, sustainability of production. Research activities should be then carried out by the active involvement of farmers in the research process, to implement their actual needs/research demand in the activities [10]. The modern apricot industry needs commercial cultivars characterized by highly fruit quality attributes [8], which can be intensified by the interaction of several factors, including the cultivation techniques under different environmental conditions and the genotype $[3,11,12]$.

As for the agronomic management systems, conventional agriculture practices are still widely adopted by farmers, resulting in the highest rate of soil erosion and pollution [13-15]. However, in recent years, crop diversification, optimized use of energy, soil and water resources, as well as strategies to counteract adverse future climatic conditions are objective of growing attention, to contribute to long-term sustainability of the agroecosystems, climate change mitigation and adaptation [16]. In accordance, the recently published, and Farm to Fork strategy (FFS) of the European Commission [17] aims to a proportion of 25\% organically managed farmland in the EU by 2030 towards more environmentally friendly and less intensive agricultural systems, with a significant reduction in fertilizer consumption and use of pesticides. The strategy refers to biodiversity, which with a separate strategy, "Bringing nature back into our lives" [18] is seen as crucial to increase the resilience of European societies. In this context, the introduction of agroecological practices can be the first step of this transformative process towards a more sustainable agriculture [19]. Sayara et al. [20] suggested to increase the orchard organic management, based on reducing the intensity of agronomic practices (e.g., tillage, fertilization, irrigation, etc.) and recycling of agricultural key compounds (nitrogen, phosporus potassium and/or organic matter) deriving from to the human activity and waste production, which can positively contribute to environmental sustainability. Moreover, the introduction of cover crops rotation, as well as intercropping, before or between principal crops as well as between shrubs or trees of plantation crops, may enhance soil chemical, physical and biological characteristics, contributing to soil health and sustaining cash crop development and yield [21,22].

In light of these considerations, our study aims to evaluate the effects of preharvest factors and orchard management on organic apricot fruit postharvest quality. In an Italian Long-Term Experiment (LTE), conducted throughout the direct engagement of local stakeholders (i.e., farmers and technician), cultivars-by-environment-by-management interactions were investigated to evaluate their potential impact in maximizing apricot quality, in terms of fruits pomological (color and weight), physico-chemical (soluble solids content, titratable acidity, dry matter and soluble solids and titratable acidity ratio) and nutraceutical characteristics (total phenolic content and antioxidant activity). The response of two cultivars (Kioto* and Pieve*) was compared under three different organic management systems based on different level of diversification for two consecutive years: a control system (Business As Usual) managed according to local standardized management practices for organic fruit orchards, an innovative diversified system with reduced tillage based on the natural cover conservation and use of an innovative diversified system with introduction of different cover crops.

\section{Materials and Methods}

\subsection{Experimental Design, Plant Materials and Pedoclimatic Data}

\subsubsection{Experimental Design and Plant Materials}

The study was carried out in 2019 and 2020 in the "maintenance of organic orchards" long-term experiment (MAIOR LTE) of CREA-Research Centre for Olive, Fruit and Citrus Crops, located in Rome, Central Italy (latitude $41.8000^{\circ} \mathrm{N}$, longitude $12.5690^{\circ} \mathrm{E}$, 
altitude $86 \mathrm{~m}$ a.s.l.). The MAIOR LTE experimental design was a split plot with 3 blocks. The main plot was assigned to the organic agronomic management, with three compared systems with a different level of diversification: (i) Business As Usual (BAU—a local common practices for organic fruit orchards management-soil tillage and organic commercial fertilizer), (ii) Innovative diversified system with Natural cover and a green Compost use (INC - no soil tillage at transplanting, natural cover, Municipal Waste Compost $\mathrm{MCW}$ ), (iii) Innovative diversified system with introduced Cover and Compost use (ICCintroduction of Agroecological Service Crops, tillage and MWC). The main features of the three compared organic systems are reported in Table 1.

Table 1. Different agronomic system management description.

\begin{tabular}{|c|c|c|c|}
\hline & BAU $^{1}$ & INC $^{2}$ & $\mathrm{ICC}^{3}$ \\
\hline Tillage & $\begin{array}{l}\text { Tillage at planting } \\
\text { Hoeing twice per year }\end{array}$ & $\begin{array}{c}\text { No tillage at planting } \\
\text { (transplanting furrow and soil } \\
\text { ripping in central inter-row space) } \\
\text { Strip hoeing for compost } \\
\text { ploughing close to the } \\
\text { apricot trees }\end{array}$ & $\begin{array}{l}\text { Tillage at planting } \\
\text { Hoeing twice per year }\end{array}$ \\
\hline Fertilization & $\begin{array}{l}\text { Commercial organic fertilizer } \\
\text { (24\% of organic Carbon and } 5 \% \text { of } \\
\text { organic N content on dry basis) } \\
\text { Distribution once per year } \\
\text { in autumn }\end{array}$ & $\begin{array}{l}\text { Municipal waste compost (37\% of } \\
\text { organic Carbon and } 2.8 \% \text { of } \\
\text { organic N content on dry basis) } \\
\text { Distribution once per year } \\
\text { in autumn }\end{array}$ & $\begin{array}{c}\text { Municipal waste compost (37\% of } \\
\text { organic Carbon and } 2.8 \% \text { of } \\
\text { organic N content on dry basis) } \\
\text { Distribution once per year } \\
\text { in autumn }\end{array}$ \\
\hline Irrigation & $\begin{array}{c}\text { Drip system } \\
\text { (About } 1500 \mathrm{~m}^{3} \mathrm{ha}^{-1} \text { from June to } \\
\text { September for } 2 \text { times a week in } \\
12 \mathrm{~h} \text { at a time) }\end{array}$ & $\begin{array}{c}\text { Drip system } \\
\text { (About } 1500 \mathrm{~m}^{3} \mathrm{ha}^{-1} \text { from June to } \\
\text { September for } 2 \text { times a week in } \\
12 \mathrm{~h} \text { at a time) }\end{array}$ & $\begin{array}{c}\text { Drip system } \\
\text { (About } 1500 \mathrm{~m}^{3} \mathrm{ha}^{-1} \text { from June to } \\
\text { September for } 2 \text { times a week in } \\
12 \mathrm{~h} \text { at a time) }\end{array}$ \\
\hline $\begin{array}{c}\text { Cover } \\
\text { management }\end{array}$ & $\begin{array}{l}\text { Natural cover, mowed twice per } \\
\text { year (spring, autumn) }\end{array}$ & $\begin{array}{c}\text { Natural cover, mowed twice per } \\
\text { year (spring, autumn) }\end{array}$ & $\begin{array}{l}\text { Natural cover (spring to autumn) } \\
\text { mowed in autumn } \\
\text { Cover crop mixtures and strips } \\
\text { sowed in autumn and terminated } \\
\text { in spring }\end{array}$ \\
\hline
\end{tabular}

${ }^{1}$ BAU: Businness As Usual; ${ }^{2}$ INC: Innovative diversified system with Natural cover and Compost; ${ }^{3}$ ICC: Innovative diversified system with introduced Cover and Compost use.

The Agroecological Service Crops (ASC) were sowed in autumn while mowed and chopped in late spring, according to a strip system: a main mixture of species (mix1) with nutritional and competitive against spontaneous flora functions was broadly sowed in the inter-row spaces, except for a central area (1 m-wide) where a flower strip with attractive function for beneficial insects was sowed (mix 2). The mix 1 was composed by Italian ryegrass, Lolium multiflorum ( $60 \%$ of pure dose standard, $\left.35 \mathrm{~kg} \mathrm{ha}^{-1}\right)$, white mustard, Sinapis alba $\left(40 \%, 2.5 \mathrm{~kg} \mathrm{ha}^{-1}\right)$, and white clover, Trifolium repens $\left(40 \%, 5 \mathrm{~kg} \mathrm{ha}^{-1}\right)$ in 2017-2018 and by oat, Avena sativa $\left(60 \%, 84 \mathrm{~kg} \mathrm{ha}^{-1}\right)$ and common vetch Vicia sativa $\left(40 \%, 44 \mathrm{~kg} \mathrm{ha}^{-1}\right)$ since autumn 2019. The mix2 was composed by Phacelia tanacetifolia $\left(90 \%, 9 \mathrm{~kg} \mathrm{ha}^{-1}\right)$, Coriander, Coriandrum sativum $\left(20 \%, 4 \mathrm{~kg} \mathrm{ha}^{-1}\right)$ and borage, Borago officinalis ( $\left.20 \% 0.4 \mathrm{~kg} \mathrm{ha}^{-1}\right)$ during the whole experiment. The ASC mixture development was evaluated by cover estimation (\%) at termination by 12 randomly selected $1 \mathrm{~m} \times 1 \mathrm{~m}$ quadrats in the row and inter-row space per ICC plot.

The split plot was assigned to the apricot (Prunus armeniaca L.) cultivars. Two selfcompatible apricot cultivars with different vigor were chosen: Kioto* $(\mathrm{KM})$ is a medium ripening (3th week of June in Central Italy) with contained vigor and high productivity, whereas Pieve* (PM) is a medium-late ripening cultivar (4th week of June in Central Italy) characterized by high vigor and good productivity. They were grafted on the same rootstock Myrobalan 29C, a clonal selection of Prunus cerasifera (able to contain the vigor of plants and suitable for all kinds of soils) and planted at spacing of 4.4 by $3 \mathrm{~m}$, and an area 
pertaining to each tree of $13.2 \mathrm{~m}^{2}$. Each sub-plot was composed by $3 \times 4$ trees $\left(132 \mathrm{~m}^{2}\right)$. The LTE started in winter 2017, at the end of a participatory process involving farmers in the identification of the studied factors to include the local stakeholders needs in the research activity [23].

Apricot samples were harvested at the homogeneous maturation grade (physiological ripening) evaluated by a tristimulus colorimeter (Chroma Meter CR-400, Minolta, Milan, Italy). Three sets of fruits (about $1.5 \mathrm{~kg}$ ) were randomly sampled in each plot and three replicates in each plot were carried out for each cultivar. Quality analyses were carried out on fresh pitted fruits, whereas determination of phytochemical characteristics was performed on samples stored at $-80^{\circ} \mathrm{C}$.

\subsubsection{Climatic Conditions}

Monthly data on mean air temperature at $2 \mathrm{~m}$ (AT_mean), average maximum temperature at $2 \mathrm{~m}$ (AT_max), average minimum temperature at $2 \mathrm{~m}$ (AT_min), soil temperature at $0.2 \mathrm{~m}(\mathrm{ST})$, relative humidity at $2 \mathrm{~m}(\mathrm{RH})$, solar radiation (SR), and rainfall (RF) were collected from weather station located nearby the experimental site during the 2-year period (from July 2018 to June 2020).

According to Köppen classification, Rome has a Mediterranean climate, characterized by mild winters and warm to hot summers. On average, January is the coldest month $\left(7.5^{\circ} \mathrm{C}\right)$, whilst July and August are the hottest $\left(25.1\right.$ and $25.4{ }^{\circ} \mathrm{C}$, respectively) and driest. November and December are the wettest months, with an average rainfall of 110-120 mm/month. During the apricot growing season (from March to June), the longterm mean air temperature recorded " $1971-2000$ " varied from $10^{\circ} \mathrm{C}$ to $23^{\circ} \mathrm{C}$, with an average minimum temperature above $5^{\circ} \mathrm{C}$ and an average maximum temperature below $32{ }^{\circ} \mathrm{C}$. Precipitation was equally distributed during March-May, with monthly average values equal to $75-80 \mathrm{~mm}$, while June was slightly drier $(45 \mathrm{~mm})$.

The climate variables recorded during the two experimental years (from July 2018 to June 2020) are shown in Table 2 . The monthly mean air temperature ranged between $6.0^{\circ} \mathrm{C}$ (January 2019) and $26.4^{\circ} \mathrm{C}$ (July and August 2019). The highest mean temperature was recorded in August 2019 (AT_max $=33.7^{\circ} \mathrm{C}$ ), whereas the lowest in January 2019 (AT_min $=3.3^{\circ} \mathrm{C}$ ). In winter, minimum temperatures rarely dropped below $0{ }^{\circ} \mathrm{C}$, whereas in summer maximum temperatures were often over $30^{\circ} \mathrm{C}$, especially in 2019 . The mean air temperature during the growing season was $16.1^{\circ} \mathrm{C}$ for 2019 and $16.5^{\circ} \mathrm{C}$ for 2020 . Soil temperature followed the same trend as the air temperature: mean ST never dropped below $6.2^{\circ} \mathrm{C}$ (January 2019) or rise above $26.4{ }^{\circ} \mathrm{C}$ (July 2018). Mean solar radiation varied from $53 \mathrm{~W} \mathrm{~m}^{-2}$ (December 2019) to $277 \mathrm{~W} \mathrm{~m}^{-2}$ (June 2019). The rainfall distribution differed greatly from the long-term trend: during 2019 and 2020 growing season, rainfall was significantly higher and lower than long-term averages $(+16 \%$ and $-51 \%$, respectively). Moreover, May 2019 was an extremely rainy month $(212.8 \mathrm{~mm})$, while it never rained in the following month. In the same period of 2020, the total amount of rainfall was very low, especially in May $(14.6 \mathrm{~mm})$. At last, the maximum monthly average relative humidity was recorded in November 2019 (88.2\%), corresponding to the maximum rainfall (302.6 mm), whereas the minimum RH in July 2019 (63.8\%). 
Table 2. Mean monthly meteorological data of the two experimental years (2018-2019 and 2019-2020).

\begin{tabular}{|c|c|c|c|c|c|c|c|}
\hline & $\underset{\left({ }^{\circ} \mathrm{C}\right)}{\text { AT_MIN }}$ & $\underset{\left({ }^{\circ} \mathrm{C}\right)}{A T+M A X}$ & $\underset{\left({ }^{\circ} \mathrm{C}\right)}{\text { AT_MEAN }}$ & $\begin{array}{l}\text { RH } \\
(\%)\end{array}$ & $\begin{array}{c}\text { SR } \\
(\mathrm{W} / \mathrm{M} 2)\end{array}$ & $\begin{array}{l}\text { ST } \\
\left({ }^{\circ} \mathrm{C}\right)\end{array}$ & $\begin{array}{c}\text { RF } \\
(\mathrm{MM})\end{array}$ \\
\hline JUL-18 & 20.8 & 32.9 & 26.2 & 65.7 & 266 & 26.4 & 40.8 \\
\hline AUG-18 & 20.6 & 33.1 & 24.9 & 74.9 & 209 & 24.9 & 120.2 \\
\hline SEP-18 & 17.4 & 28.7 & 21.7 & 78.3 & 172 & 22.7 & 47.8 \\
\hline OCT-18 & 14.8 & 24.1 & 18.1 & 80.8 & 102 & 18.6 & 156.6 \\
\hline NOV-18 & 10.2 & 17.8 & 13.1 & 84.3 & 64 & 14.0 & 131.8 \\
\hline DEC-18 & 5.9 & 13.6 & 8.8 & 87.4 & 72 & 9.6 & 35.0 \\
\hline JAN-19 & 3.3 & 10.8 & 6.0 & 82.2 & 59 & 6.2 & 85.0 \\
\hline FEB-19 & 5.3 & 15.3 & 9.0 & 75.5 & 105 & 7.7 & 56.6 \\
\hline MAR-19 & 7.8 & 18.1 & 11.7 & 75.3 & 146 & 10.2 & 19.0 \\
\hline APR-19 & 10.0 & 19.4 & 13.5 & 81.1 & 182 & 12.9 & 89.8 \\
\hline MAY-19 & 11.6 & 19.8 & 14.9 & 85.8 & 184 & 15.1 & 212.8 \\
\hline JUN-19 & 19.2 & 32.3 & 24.4 & 70.0 & 277 & 20.7 & 0.4 \\
\hline JUL-19 & 21.2 & 33.1 & 26.4 & 63.8 & 260 & 25.1 & 24.2 \\
\hline AUG-19 & 21.8 & 33.7 & 26.4 & 64.8 & 230 & 25.7 & 18.2 \\
\hline SEP-19 & 18.0 & 28.5 & 22.1 & 72.8 & 171 & 22.8 & 37.2 \\
\hline OCT-19 & 14.4 & 24.3 & 17.9 & 81.1 & 118 & 18.1 & 51.0 \\
\hline NOV-19 & 12.1 & 17.5 & 14.0 & 88.2 & 55 & 15.2 & 302.6 \\
\hline DEC-19 & 8.1 & 14.9 & 10.0 & 82.9 & 53 & 11.1 & 73.2 \\
\hline JAN-20 & 4.7 & 14.0 & 7.6 & 83.8 & 68 & 6.7 & 16.0 \\
\hline FEB-20 & 7.3 & 16.6 & 10.4 & 75.8 & 117 & 8.9 & 8.2 \\
\hline MAR-20 & 8.0 & 16.7 & 10.9 & 76.3 & 158 & 9.8 & 51.8 \\
\hline APR-20 & 10.4 & 20.7 & 14.0 & 78.4 & 205 & 13.8 & 33.6 \\
\hline MAY-20 & 15.5 & 25.5 & 19.2 & 66.3 & 237 & 18.2 & 14.6 \\
\hline JUN-20 & 18.5 & 27.4 & 21.9 & 69.5 & 268 & 21.2 & 36.6 \\
\hline
\end{tabular}

Legend: AT_min = average minimum temperature; AT_max = average maximum temperature; AT_mean = mean air temperature; $\mathrm{RH}=$ relative humidity; $\mathrm{SR}=$ solar radiation; $\mathrm{ST}=$ soil temperature; $\mathrm{RF}=$ rainfall.

\subsubsection{Soil Characterizations}

Soils from each management system were sampled (0-25 depth) each year in early spring. The samples were dried for $48 \mathrm{~h}$ at $70{ }^{\circ} \mathrm{C}$ and then analyzed for Total Nitrogen $(\mathrm{N})$ and Total Organic Carbon (TOC) contents by elemental LECO Nitrogen and TOC analyzers (mod. FP-528 and RC-612, respectively; St. Joseph, MI, USA) using Dumas and dry combustion methods, respectively. The main total nitrogen and total organic carbon soil content of the different systems management are presented in Figure 1.

Soils showed significant highest TOC content $(p<0.05)$ for the INC system in the

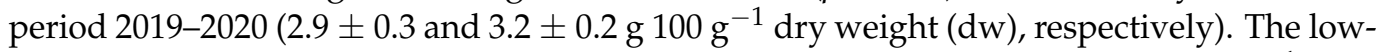
est TOC content was observed for BAU and ICC during $2019\left(2.6 \pm 0.3 \mathrm{~g} 100 \mathrm{~g}^{-1} \mathrm{dw}\right)$. As for $\mathrm{N}$ content, significant different values were observed between BAU and ICC $(6.3 \pm 0.4$ and $7.0 \pm 0.1 \mathrm{ppm} \mathrm{dw}$, respectively), and INC ( $3.7 \pm 0.6 \mathrm{ppm} \mathrm{dw})$ during 2020. In general, ICC and BAU showed similar trends for $\mathrm{N}$ and TOC contents, whilst INC strongly differed from the others.

\subsection{Fruit Quality Traits}

Fruits were weighed, and the ground skin color on the external opposite sides (two readings in the equatorial perimeter) of all unpeeled fruits was assessed by the CIELab color space coordinates of a tristimulus colorimeter (Chroma Meter CR-200; Minolta, Milan, Italy), equipped with a D65 illuminant [9]. The instrument was calibrated with a standard calibration plate and the results, $\mathrm{L}^{*}, \mathrm{a}^{*}, \mathrm{~b}^{*}$, were reported as means of the two opposite fruit sides. Similar procedure was applied to determinate the flesh color. An aliquot of fresh fruit was used to determine the dry matter (DM) using an oven (Tecnocalor 2000 model M60-VF Tecnovetro, Monza, Italy) calibrated at $105^{\circ} \mathrm{C} \pm 1$, until a constant weight was reached. In order to measure the titratable acidity (TA), fruits (about $400 \mathrm{~g}$ per each cultivar, year and system management) were deprived of stones and homogenized using an automatic titration system (785 DPM Titrino, Metrohm Ldt, Herisau, Switzerland), according to Ceccarelli et al. [24]. The TA content was expressed as gram (g) of malic acid (MA) $100 \mathrm{~g}^{-1}$ fresh weight (FW) of edible fruits. Soluble solids content (SSC) was determined on fruit 
juice with a digital refractometer (Refracto 30PX, Mettler Toledo, Greifensee, Switzerland) and expressed as $\mathrm{g} 100 \mathrm{~g}^{-1} \mathrm{FW}$ (Brix degrees).

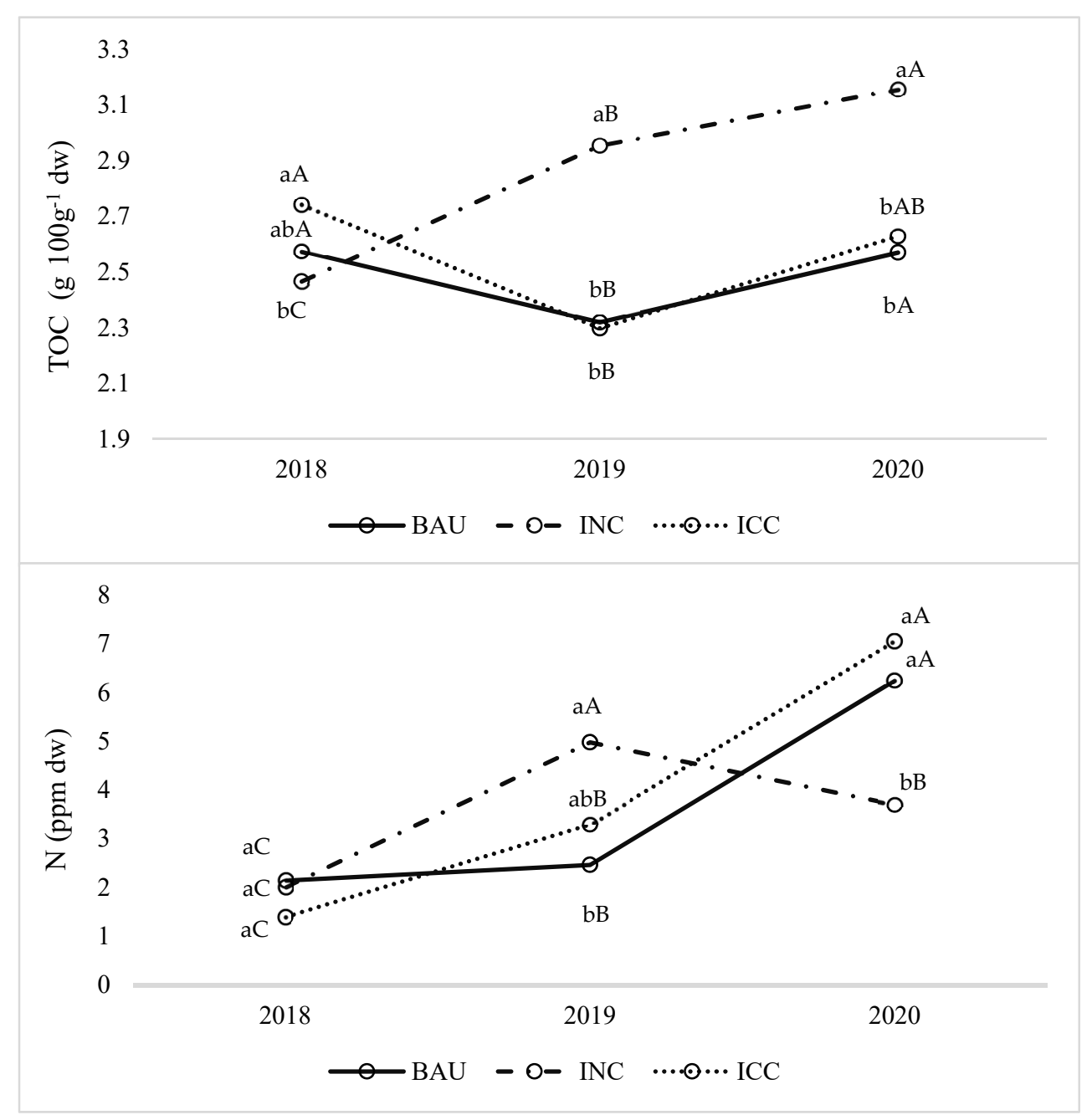

Figure 1. Soil total organic carbon (TOC) and total nitrogen (N) variability among the different system management during the three years. Legend: Values belonging the same parameters without common letters are statistically different according to Kruskal Wallis test $(p<0.05)$. Upper case letters refer to differences among years for each treatment; lower case letters refer to differences among treatments within the same year.

\subsection{Chemicals}

All reagents were of analytical High-Performance Liquid Chromatography (HPLC) grade (Merk Life Science S.r.l, Milan, Italy). Folin-Ciocalteau reagent, 2,2-diphenyl-1picrylhydrazyl (DPPH), ( \pm )-6-hydroxy-2,5,7,8-tetramethylchromane-2-carboxylic acid common called Trolox (T), sodium carbonate and gallic acid (GA) were purchased from SigmaAldrich (St Louis, MO, USA).

\subsection{Extraction and Total Phenolic Content and Antioxidant Activity Determinations}

About $5 \mathrm{~g}$ of fresh whole fruit were homogenized with a blender (Ultra-Turrax T25, IKA Labortechnik, Staufen, Germany) in $25 \mathrm{~mL}$ of acidified methanol water solution (methanol/water 70/30 v/v with $5 \mathrm{mM} \mathrm{HCl}$ ) to determine both total phenolic content (TPC) and antioxidant activity (AA), according to Ceccarelli et al. [24]. The extraction was carried out under shaking in a thermostatic bath at $37^{\circ} \mathrm{C}$ for $2 \mathrm{~h}$ and centrifugation at $5{ }^{\circ} \mathrm{C}$ and $8000 \times g$ for $15 \mathrm{~min}$ (centrifuge mod. 4239R, ALC International, Milan, Italy). Finally, the supernatant was recovered. The TPC was determined by the Folin-Ciocalteu method, as 
reported by Ceccarelli et al. [24]. Results were calculated and expressed as mg of gallic acid equivalent (GAE) $100 \mathrm{~g}^{-1} \mathrm{FW}$. Determination of GAE was performed by GA standard curve $\left(0.025-0.5 \mathrm{mg} \mathrm{mL}^{-1}\right)$. Briefly, $0.4 \mathrm{~mL}$ of extract were added to $16.0 \mathrm{~mL}$ water, $2.0 \mathrm{~mL}$ of Folin-Ciocalteu phenol reagent, $6.0 \mathrm{~mL}$ of $1 \mathrm{M}$ sodium carbonate and the final volume was adjusted to $25 \mathrm{~mL}$ with the same solution used for the extraction. The TPC of the extracts was determined spectrophotometrically at $760 \mathrm{~nm}$ after $2 \mathrm{~h}$ using an Evolution $300 \mathrm{UV}-\mathrm{Vis}$ Spectrophotometer (Thermo Electron Scientific Instruments, Madison, WI, USA). In the end, AA of the extracts was determined by DPPH (1,1-diphenyl-2-picrylhydrazyl) method, as described by Ceccarelli et al. [24]. $1.5 \mathrm{~mL}$ of DPPH solution was added to $1.5 \mathrm{~mL}$ of fruit extract and, after $15 \mathrm{~min}$, absorbance at $515 \mathrm{~nm}$ was determined using the UV-Vis Spectrophotometer. Trolox $\left(0.5-10 \mu \mathrm{g} \mathrm{mL}^{-1}\right)$ was used as reference compound and AA was expressed as $\mu \mathrm{g}$ of Trolox equivalent (TE) $100 \mathrm{mg}^{-1} \mathrm{FW}$.

\subsection{Statistical Analysis}

Descriptive statistics, including mean, standard deviation (SD), minimum (Min) and maximum (Max) value, 25th percentile (Q1), median, and 75th percentile (Q3) were calculated for SSC, TA, DM, TPC, and AA. Generalized linear model (GzLM) was applied to assess the influence of three factors (cultivar, year and management system) and all their two-way interactions on SSC, TA, DM, TPC, and AA. In GzLM, the response variable Y has a probability distribution from the exponential family with mean $\mathrm{E}[\mathrm{Y}]=\mu$. GzLM estimates the relationship between the mean value of the response variable and a linear combination of the explanatory variables $X$, which are connected by a link function $g$ as follows:

$$
\eta=g(\mu)=X \beta
$$

where $g(\mu)^{\prime}=\left[g\left(\mu_{1}\right), \ldots, g\left(\mu_{n}\right)\right]^{\prime}$ is the $n \times 1$ vector of link functions, $X$ is the $\mathrm{n} \times(\mathrm{p}+1)$ predictors matrix, and $\beta$ is the $(p+1) \times 1$ vector of unknown parameters.

In our study, we assumed that each of the response variables Y (SSC, TA, DM, TPC or AA) followed a gamma distribution and the logarithm of its expected value $E(Y)$ could be modelled by a linear combination of parameters. The gamma distribution is commonly used for continuous, non-negative and skewed response variables. In our study, gamma regression models GzLM with the logarithm as the canonical link function and the Gamma distribution function were applied. In detail the statistical model was:

$$
\eta=g(\mu)=\log (Y)=\beta_{0}+\tau_{i}+\delta_{1}+\zeta_{k}+\tau_{\iota} \delta_{1}+\tau_{\iota} \zeta_{k}+\delta_{1} \zeta_{k}+\varepsilon_{\text {ilk }}
$$

where $\mathrm{Y}=\mathrm{SSC}$ or TA or DM or TPC or AA; $\beta_{0}=$ average effect common to all observations; $\tau_{\mathrm{i}}=$ cultivar $(\mathrm{CV}), \mathrm{i}=1,2(1=\mathrm{KM}, 2=\mathrm{PM}) ; \delta_{1}=$ year, $1=1,2(1=2019,2=2020)$; $\zeta_{\mathrm{k}}=$ management system $(\mathrm{M}), \mathrm{k}=1,2,3$ (1 = BAU, $\left.2=\mathrm{ICC}, 3=\mathrm{INC}\right) ; \varepsilon=$ error term.

Parameters in GzLM are estimated using maximum likelihood. Hypothesis tests are constructed using Wald-type statistics based on the maximum likelihood estimators. The overall fit of GzLM model could be measured by the deviance statistic, i.e., twice the difference between two log-likelihoods, which can be approximated by a chi-square distribution for sufficiently large sample sizes. Therefore, a Likelihood Ratio Chi-Square was used to test the goodness-of-fit. The deviance generalizes the sum of squared errors in normal linear models.

Finally, Principal Component Analysis (PCA) was performed on the quality attributes and nutraceutical parameters (SSC, TA, DM, TPC or AA) in order to highlight similarities among apricot samples and clustering tendencies for cultivars and management systems.

Non-parametric Kruskal Wallis test was also applied to evaluate significant differences in TOC and N values among management systems during the 2018-2020 period. 


\section{Results}

\subsection{Fruit Apricot General Aspects}

The three tested factors (cultivar, year and organic system management) showed no significant effect on apricot fruits weight and color. Mean values of fresh weight ranged from $23.6 \mathrm{~g}$ to $49.9 \mathrm{~g}$ for Pieve* and from $23.5 \mathrm{~g}$ to $48.3 \mathrm{~g}$ for Kioto*, highlighting a high variability inside each cultivar (Table S1). The variability found in each cultivar was clearly higher than that due to the harvest years and system management. Regarding skin color (Table S1), coordinates showed a slight variability among the organic system managements, harvest years and cultivars (overall mean values $\mathrm{L}^{*} 51.32 \pm 3.31$, $\mathrm{a}^{*} 19.84 \pm 3.24, \mathrm{~b}^{*} 32.24 \pm 3.64$ ), confirming similar apricot ripening state. Analogous behaviors were also observed for fruit flesh color coordinates (overall mean values $\mathrm{L}^{*} 54.82 \pm 2.72$, $\mathrm{a}^{*} 12.01 \pm 3.04, \mathrm{~b}^{*} 40.23 \pm 3.14$ ).

\subsection{Cultivars Variability}

As previously reported, the CIELab coordinates were measured in field on fruits skin to assess the ripening stage and successively on the flesh for both harvest experimental years. On average, Kioto* showed the highest values for skin (Skin $L^{*}=52.76 \pm 2.83$, Skin $\mathrm{a}^{*}=20.58 \pm 3.75$, Skin $\mathrm{b}^{*}=35.16 \pm 5.24$ for Kioto ${ }^{*}$ and Skin $\mathrm{L}^{*}=49.87 \pm 3.84$, Skin $\mathrm{a}^{*}=19.93 \pm 5.00$, Skin $\mathrm{b}^{*}=30.79 \pm 4.53$ for Pieve* ${ }^{*}$ and flesh coordinates (Flesh $\mathrm{L}^{*}=55.57 \pm 2.70$, Flesh $\mathrm{a}^{*}=12.64 \pm 2.92$, Flesh $\mathrm{b}^{*}=40.35 \pm 3.02$ for Kioto*, and Flesh $\mathrm{L}^{*}=54.13 \pm 2.45$, Flesh $\mathrm{a}^{*}=12.38 \pm 2.89$, Flesh $\mathrm{b}^{*}=39.68 \pm 3.46$ for Pieve ${ }^{*}$ ) as previously reported in Table S1.

Regarding other qualitative parameters, the cultivars considerably differed in their SSC and DM values (Table 3). The soluble solids content was higher for Pieve* than Kioto*

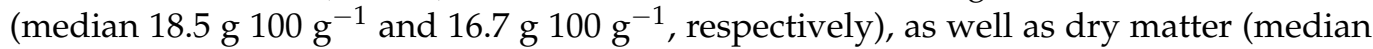

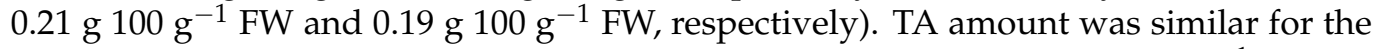
two cultivars, although Kioto* was slightly higher (median $20.3 \mathrm{~g} \mathrm{MA}^{*} 100 \mathrm{~g}^{-1} \mathrm{FW}$ for KM and $19.6 \mathrm{~g}^{\mathrm{MA}} 100 \mathrm{~g}^{-1}$ FW for PM). High SSC/TA ratio was calculated for the two cultivars: Pieve* ranged from 0.89 to 1.09 and Kioto* between 0.78 and 0.98 (Table 3). A high variability in the total phenol content and the antioxidant activity was observed for both apricot cultivars (Table 3). Indeed, TPC ranged from 211 to $528 \mathrm{mg} \mathrm{GAE} 100 \mathrm{~g}^{-1} \mathrm{FW}$ for Kioto* and from 273 to 565 mg GAE $100 \mathrm{~g}^{-1}$ FW for Pieve*, whereas AA varied between 0.80 and $1.83 \mu \mathrm{g}$ TE $100 \mathrm{mg}^{-1}$ FW for Kioto* and between 0.81 and $1.70 \mu \mathrm{g}$ TE $100 \mathrm{mg}^{-1}$ FW for Pieve*.

\subsection{Management Systems Variability}

The organic management systems had no significant effect on color coordinates

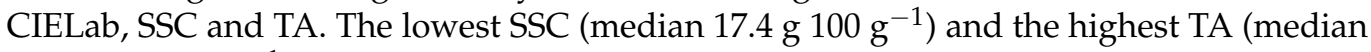
$21.5 \mathrm{~g}$ MA $100 \mathrm{~g}^{-1} \mathrm{FW}$ ) values were observed when ICC was applied, contrary to what was recorded for BAU (Table 3). Consequently, the lowest SSC/TA ratio was observed in fruits harvested when ICC management was used (0.8), whereas the highest one was found in BAU (1.0) (Table S2). Likewise, DM was lower for the ICC system than for BAU and INC. Significant differences and high variability were observed for the total phenolic content and the antioxidant activity. TPC for ICC system was greatly higher than BAU and INC (median 462 mg GAE $100 \mathrm{~g} \mathrm{~g}^{-1}$ FW (ICC PM), 449 mg GAE $100 \mathrm{~g}^{-1}$ FW (ICC KM), $411 \mathrm{mg}$

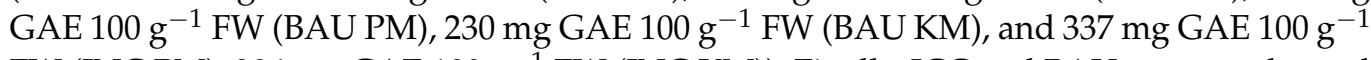
FW (INC PM), 306 mg GAE $100 \mathrm{~g}^{-1} \mathrm{FW}$ (INC KM)). Finally, ICC and BAU systems showed higher AA values than INC (median 1.14, 1.14 and $0.99 \mu \mathrm{g}$ TE $100 \mathrm{mg}^{-1} \mathrm{FW}$, respectively). 
Table 3. Descriptive statistics, including mean, standard deviation (SD), minimum (Min) and maximum (Max) values, 25th percentile (Q1), median, and 75th percentile (Q3), for quality parameters, as a function of cultivar (Kioto* KM and Pieve* PM) and agronomic treatment (Business As Usual-BAU; Innovative diversified system with Natural cover and Compost use-ICC; Innovative diversified system with introduced Cover and Compost use-INC).

\begin{tabular}{|c|c|c|c|c|c|c|c|c|c|}
\hline & $\mathrm{CV}$ & $\operatorname{Tr}$ & Mean & SD & Min & $\operatorname{Max}$ & Q1 & Median & Q3 \\
\hline \multirow{8}{*}{ SSC } & \multirow{4}{*}{$\mathrm{KM}$} & BAU & 17.7 & 3.5 & 13.6 & 21.6 & 14.4 & 17.7 & 21.1 \\
\hline & & ICC & 17.2 & 2.6 & 14.3 & 20.3 & 14.7 & 17.1 & 19.7 \\
\hline & & INC & 17.5 & 2.8 & 14.3 & 22.3 & 15.1 & 16.7 & 20.0 \\
\hline & & KM_Overall & 17.4 & 2.9 & 13.6 & 22.3 & 14.6 & 16.7 & 20.3 \\
\hline & \multirow{4}{*}{ PM } & BAU & 20.1 & 2.9 & 16.2 & 24.1 & 17.4 & 20.0 & 22.7 \\
\hline & & ICC & 17.5 & 1.4 & 15.1 & 20.0 & 16.6 & 17.4 & 18.7 \\
\hline & & INC & 19.5 & 3.0 & 14.3 & 22.6 & 16.9 & 20.8 & 21.9 \\
\hline & & PM_Overall & 19.0 & 2.7 & 14.3 & 24.1 & 16.9 & 18.5 & 21.7 \\
\hline \multirow{8}{*}{ TA } & \multirow{4}{*}{ KM } & BAU & 19.8 & 3.1 & 15.7 & 25.2 & 17.3 & 18.3 & 22.2 \\
\hline & & ICC & 20.8 & 3.1 & 16.4 & 25.4 & 17.8 & 20.7 & 23.5 \\
\hline & & INC & 21.4 & 2.4 & 17.9 & 26.7 & 19.6 & 21.1 & 22.3 \\
\hline & & KM_Overall & 20.6 & 2.9 & 15.7 & 26.7 & 18.0 & 20.3 & 23.2 \\
\hline & \multirow{4}{*}{ PM } & BAU & 18.0 & 0.8 & 16.9 & 19.8 & 17.3 & 17.8 & 18.5 \\
\hline & & ICC & 21.3 & 0.9 & 19.3 & 22.5 & 20.7 & 21.5 & 22.1 \\
\hline & & INC & 19.2 & 1.9 & 15.5 & 22.3 & 18.0 & 19.6 & 20.5 \\
\hline & & PM_Overall & 19.5 & 1.9 & 15.5 & 22.5 & 17.8 & 19.6 & 21.0 \\
\hline \multirow{8}{*}{ SSC:TA } & \multirow{4}{*}{ KM } & BAU & 0.8 & 0.1 & 0.6 & 1.1 & 0.7 & 0.8 & 0.9 \\
\hline & & ICC & 0.9 & 0.3 & 0.5 & 1.2 & 0.8 & 0.8 & 1.1 \\
\hline & & INC & 1.0 & 0.2 & 0.8 & 1.3 & 0.8 & 1.0 & 1.2 \\
\hline & & KM_Overall & 0.9 & 0.2 & 0.6 & 1.2 & 0.8 & 0.9 & 1.1 \\
\hline & \multirow{4}{*}{ PM } & BAU & 0.9 & 0.1 & 0.7 & 1.1 & 0.7 & 0.9 & 1.0 \\
\hline & & ICC & 0.9 & 0.2 & 0.6 & 1.3 & 0.8 & 0.9 & 1.0 \\
\hline & & INC & 1.1 & 0.2 & 0.8 & 1.3 & 0.8 & 1.1 & 1.2 \\
\hline & & KM_Overall & 1.0 & 0.2 & 0.7 & 1.3 & 0.8 & 1.0 & 1.1 \\
\hline \multirow{8}{*}{$\mathrm{DM}$} & \multirow{4}{*}{$\mathrm{KM}$} & BAU & 0.20 & 0.06 & 0.14 & 0.26 & 0.14 & 0.19 & 0.25 \\
\hline & & ICC & 0.19 & 0.03 & 0.15 & 0.24 & 0.16 & 0.18 & 0.22 \\
\hline & & INC & 0.19 & 0.02 & 0.16 & 0.22 & 0.17 & 0.19 & 0.21 \\
\hline & & KM_Overall & 0.19 & 0.04 & 0.14 & 0.26 & 0.16 & 0.19 & 0.22 \\
\hline & \multirow{4}{*}{ PM } & BAU & 0.22 & 0.03 & 0.18 & 0.28 & 0.20 & 0.21 & 0.25 \\
\hline & & ICC & 0.20 & 0.02 & 0.18 & 0.23 & 0.18 & 0.19 & 0.21 \\
\hline & & INC & 0.22 & 0.02 & 0.19 & 0.26 & 0.20 & 0.23 & 0.24 \\
\hline & & PM_Overall & 0.21 & 0.03 & 0.18 & 0.28 & 0.19 & 0.21 & 0.24 \\
\hline \multirow{8}{*}{ TPC } & \multirow{4}{*}{$\mathrm{KM}$} & BAU & 303 & 121 & 211 & 500 & 218 & 230 & 433 \\
\hline & & ICC & 429 & 95 & 299 & 528 & 334 & 449 & 517 \\
\hline & & INC & 289 & 38 & 234 & 325 & 243 & 306 & 321 \\
\hline & & KM_Overall & 341 & 110 & 211 & 528 & 235 & 316 & 433 \\
\hline & \multirow{4}{*}{ PM } & BAU & 383 & 59 & 277 & 436 & 336 & 411 & 427 \\
\hline & & ICC & 444 & 88 & 302 & 565 & 372 & 462 & 504 \\
\hline & & INC & 358 & 64 & 273 & 475 & 334 & 337 & 393 \\
\hline & & PM_Overall & 395 & 79 & 273 & 565 & 335 & 398 & 445 \\
\hline \multirow{8}{*}{ AA } & \multirow{4}{*}{$\mathrm{KM}$} & BAU & 1.18 & 0.28 & 0.85 & 1.58 & 0.92 & 1.14 & 1.44 \\
\hline & & ICC & 1.16 & 0.23 & 0.85 & 1.57 & 0.97 & 1.15 & 1.24 \\
\hline & & INC & 1.23 & 0.45 & 0.80 & 1.83 & 0.81 & 1.14 & 1.68 \\
\hline & & KM_Overall & 1.19 & 0.33 & 0.80 & 1.83 & 0.85 & 1.15 & 1.48 \\
\hline & \multirow{4}{*}{ PM } & BAU & 1.18 & 0.29 & 0.86 & 1.54 & 0.90 & 1.15 & 1.5 \\
\hline & & ICC & 1.11 & 0.31 & 0.84 & 1.68 & 0.85 & 1.02 & 1.23 \\
\hline & & INC & 1.16 & 0.38 & 0.81 & 1.70 & 0.83 & 1.00 & 1.62 \\
\hline & & PM_Overall & 1.15 & 0.32 & 0.81 & 1.70 & 0.86 & 1.03 & 1.46 \\
\hline
\end{tabular}

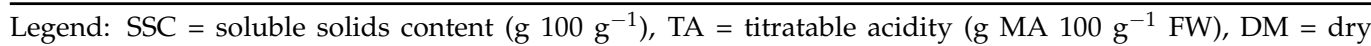
matter $\left(\mathrm{g} 100 \mathrm{~g}^{-1} \mathrm{FW}\right), \mathrm{TPC}=$ total phenolic content $\left(\mathrm{mg}\right.$ GAE $\left.100 \mathrm{~g}^{-1} \mathrm{FW}\right)$ and AA $=$ antioxidant activity ( $\mu \mathrm{g}$ TE $\left.100 \mathrm{mg}^{-1} \mathrm{FW}\right)$.

\subsection{Year Variability}

Fruit flesh and skin did not show significant differences in lightness, blue-yellow and green-red values between the two harvest years (Figure 2). 


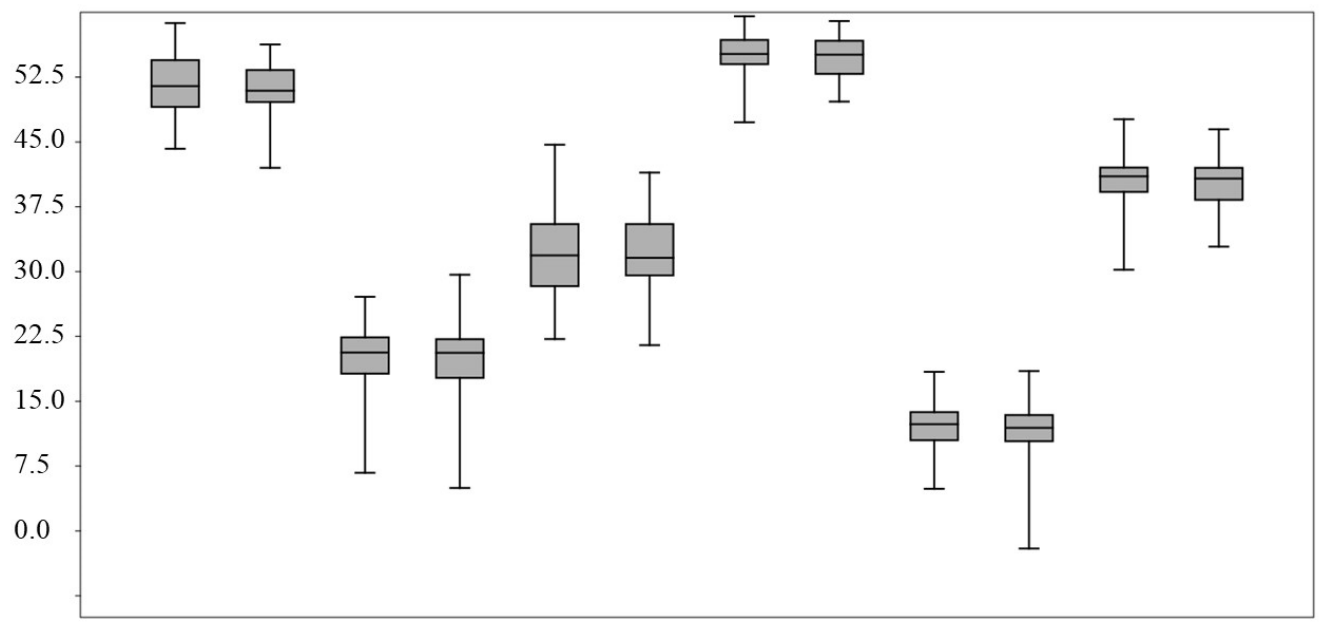

Skin L* Skin L* Skin a* Skin a* Skin $\mathrm{b}^{*}$ Skin $\mathrm{b}^{*}$ Flesh L* Flesh L* Flesh a* Flesh a* Flesh b* Flesh b*

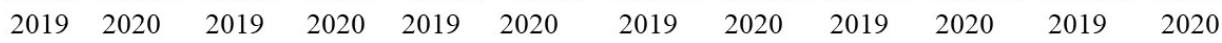
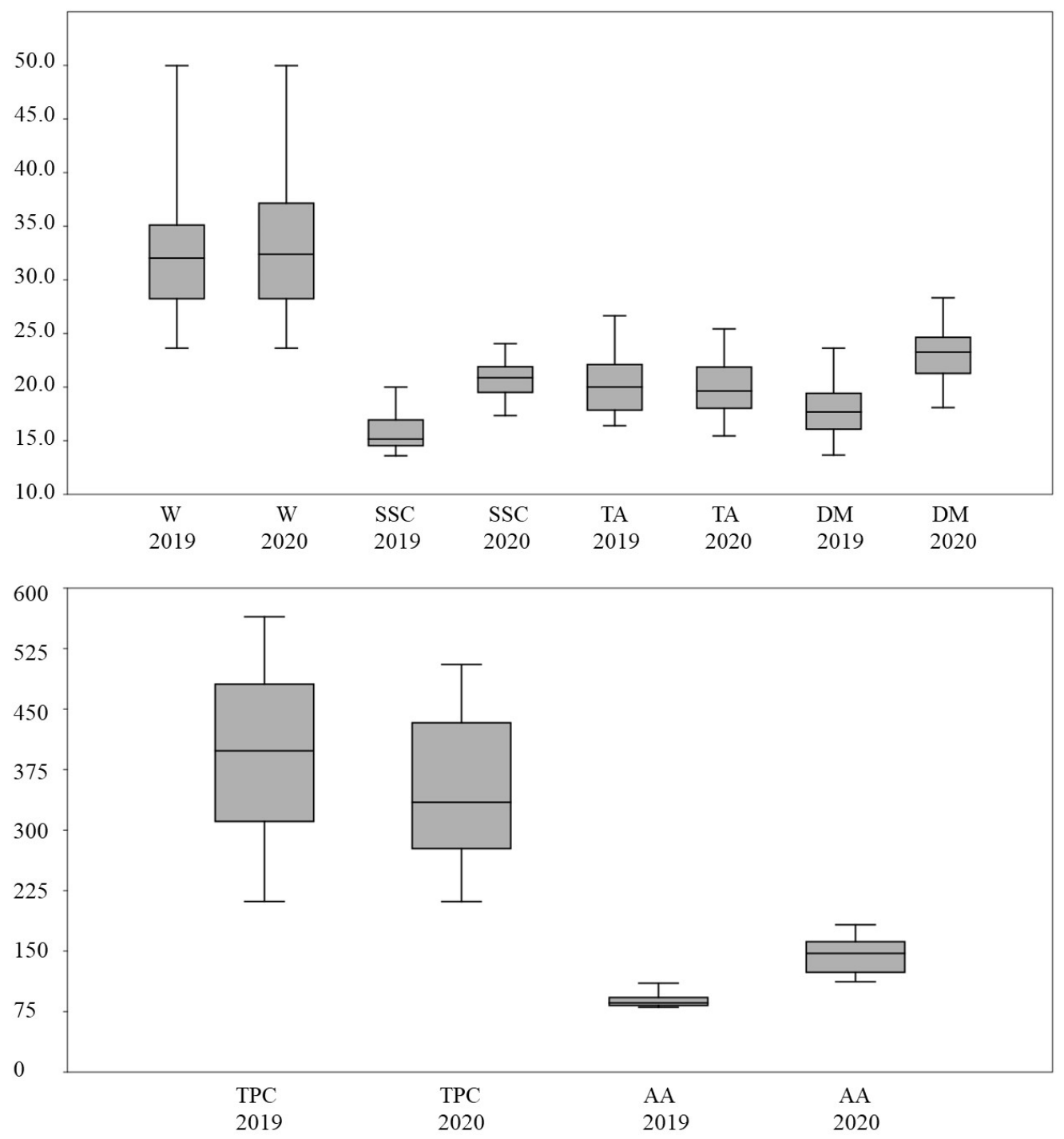

Figure 2. Box plots of CIELab coordinates of skin and flesh (Skin $L^{*}$, Skin $a^{*}$, Skin $b^{*}$, Flesh $L^{*}$, Flesh $a^{*}$, and Flesh $b^{*}$ ); $\mathrm{W}=$ weight $(\mathrm{g}), \mathrm{SSC}=$ soluble solids content $\left(\mathrm{g} 100 \mathrm{~g}^{-1} \mathrm{FW}\right), \mathrm{TA}=$ titratable acidity $\left(\mathrm{g}\right.$ MA $\left.100 \mathrm{~g}^{-1} \mathrm{FW}\right), \mathrm{DM}=$ dry matter $\left(\mathrm{g} 100 \mathrm{~g}^{-1} \mathrm{FW}\right), \mathrm{TPC}=$ total phenolic content $\left(\mathrm{mg} \mathrm{GAE} 100 \mathrm{~g}^{-1} \mathrm{FW}\right)$, and AA = antioxidant activity $\left(\mu \mathrm{g}\right.$ TE $\left.10 \mathrm{~g}^{-1} \mathrm{FW}\right)$ per year. 
Apricot mean weight showed no significant differences between the two years (from 23.6 to $50.0 \mathrm{~g}$ in 2019 and from 24.1 to $49.5 \mathrm{~g}$ in 2020), while fruits harvested in 2020 (year characterized by the lower rainfall and relative humidity) exhibited the highest SSC and

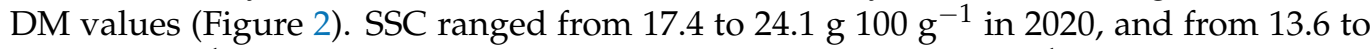

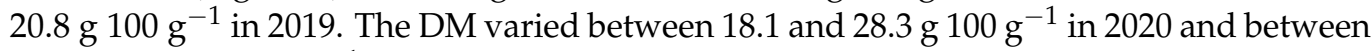

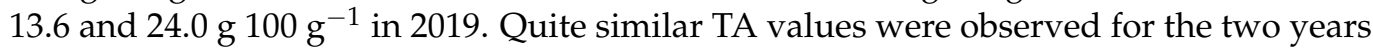
(Figure 2). Furthermore, average SSC/TA ratio for 2019 showed the highest values (1.0) respect to $2020(0.8)$.

Regarding TPC and AA, the data revealed high phenols median value (398.4 mg GAE $\left.100 \mathrm{~g}^{-1} \mathrm{FW}\right)$ and low antioxidant activity $\left(85.8 \mu \mathrm{g}\right.$ TE $\left.100 \mathrm{~g}^{-1} \mathrm{FW}\right)$ in 2019 , contrary to what was recorded in 2020 (334.6 mg GAE $100 \mathrm{~g}^{-1} \mathrm{FW}$ and $147.3 \mu \mathrm{g}$ TE $100 \mathrm{~g}^{-1} \mathrm{FW}$, respectively).

\subsection{Generalized Linear Models}

As a first step, normality of the data distributions for all parameters was checked by Shapiro-Wilk test. Because the test responses indicated that data were not normal distributed and considering that all distributions were continuous, non-negative and skewed, generalized linear models based on gamma distribution for each response variable were applied, in order to assess the overall influence of three factors (cultivar, year and management system) on all variables. No significant differences were observed for fruit fresh weight and CIELab color coordinates of fruit skin and flesh. Therefore, these parameters were not considered for GzLM. Table 4 showed the results of the analysis concerning the effect of cultivar, organic management system and year on five parameters. GzLM model for SSC showed that two single factors (cultivar and year) were statistically significant $(p=0.0002$ and $p<0.0001$, respectively), as was their two-way interaction $(p=0.0002)$.

Table 4. $\chi^{2}$ values and significance levels from GzLM regression for soluble solids content (SSC), titratable acidity (TA), dry matter (DM), total phenolic content (TPC), and antioxidant activity (AA).

\begin{tabular}{|c|c|c|c|c|c|c|c|c|c|c|}
\hline & \multicolumn{2}{|c|}{ SSC } & \multicolumn{2}{|c|}{ TA } & \multicolumn{2}{|c|}{ DM } & \multicolumn{2}{|c|}{ TPC } & \multicolumn{2}{|c|}{ AA } \\
\hline & $x^{2}$ & $\operatorname{Pr}>\chi^{2}$ & $x^{2}$ & $\operatorname{Pr}>x^{2}$ & $x^{2}$ & $\operatorname{Pr}>x^{2}$ & $x^{2}$ & $\operatorname{Pr}>x^{2}$ & $x^{2}$ & $\operatorname{Pr}>x^{2}$ \\
\hline $\mathrm{CV}$ & 13.66 & 0.0002 & 0.01 & 0.9282 & 40.05 & $<0.0001$ & 0.58 & 0.4461 & 0.23 & 0.6326 \\
\hline $\mathbf{M}$ & 2.94 & 0.0865 & 0.00 & 0.9967 & 44.66 & $<0.0001$ & 11.76 & 0.0006 & 12.87 & 0.0003 \\
\hline Year & 61.22 & $<0.0001$ & 0.01 & 0.9118 & 117.17 & $<0.0001$ & 4.78 & 0.0288 & 11.70 & 0.0006 \\
\hline $\mathrm{CV} \times \mathrm{M}$ & 0.98 & 0.3218 & 0.05 & 0.8151 & 0.26 & 0.6113 & 0.68 & 0.4094 & 0.73 & 0.3927 \\
\hline $\mathrm{CV} \times$ Year & 13.67 & 0.0002 & 0.01 & 0.9286 & 40.06 & $<0.0001$ & 0.58 & 0.4469 & 0.23 & 0.6325 \\
\hline $\mathbf{M} \times$ Year & 2.94 & 0.0864 & 0.00 & 0.9974 & 44.66 & $<0.0001$ & 11.75 & 0.0006 & 12.88 & 0.0003 \\
\hline
\end{tabular}

Legend: $\mathrm{CV}=$ cultivar $\mathrm{M}=$ management system. Numbers in bold were significant $(p<0.05)$.

Titratable acidity was not affected by any of the three factors. Regarding DM, all factors resulted highly significant $(p<0.0001)$, whether as single factors or in the two-way interactions, with the exception of the cultivar $\times$ treatment interaction $(p=0.6113)$. Agronomic treatment was the most significant factor for TPC $\left(\chi^{2}=11.76, p=0.0006\right)$. The year, although statistically significant $\left(\chi^{2}=4.78, p=0.0288\right)$, appeared less important than treatment, while the treatment $\times$ year interaction showed a higher weight $\left(\chi^{2}=11.75\right.$, $p=0.0006$ ). The genotype did not affect AA, whereas agronomic treatment was the main contributing factor to AA $\left(\chi^{2}=12.87, p=0.0003\right)$, followed by year $\left(\chi^{2}=11.70, p=0.0003\right)$ and their two-way interaction $\left(\chi^{2}=12.88, p=0.0003\right)$.

\subsection{Clustering Tendencies}

Principal Component Analysis was used to visualize simultaneously the cultivars, the management systems and harvest years on the base of their chemical properties and antiradical potential similarity and to highlight those metabolites contributing mostly to their grouping. The first two principal components (PC1 and PC2) accounted for $49.9 \%$ and $23.4 \%$ of the total observed variance, respectively. PC1 was positively correlated with 
SSC, AA and DM content, whereas PC2 was positively correlated with TPC and TA content (Figure 3). PCA emphasized the different response of the two cultivars and the three organic management systems over the two years. Indeed, the biplot showed two clusters closely related to the environmental conditions (i.e., years). The first group was on the right side and depicted the behavior of the apricot samples in 2020, characterized by high values of SSC, DM and AA. The second was on the left side and represented the behavior of the samples in 2019, with low values of SSC, DM and AA.

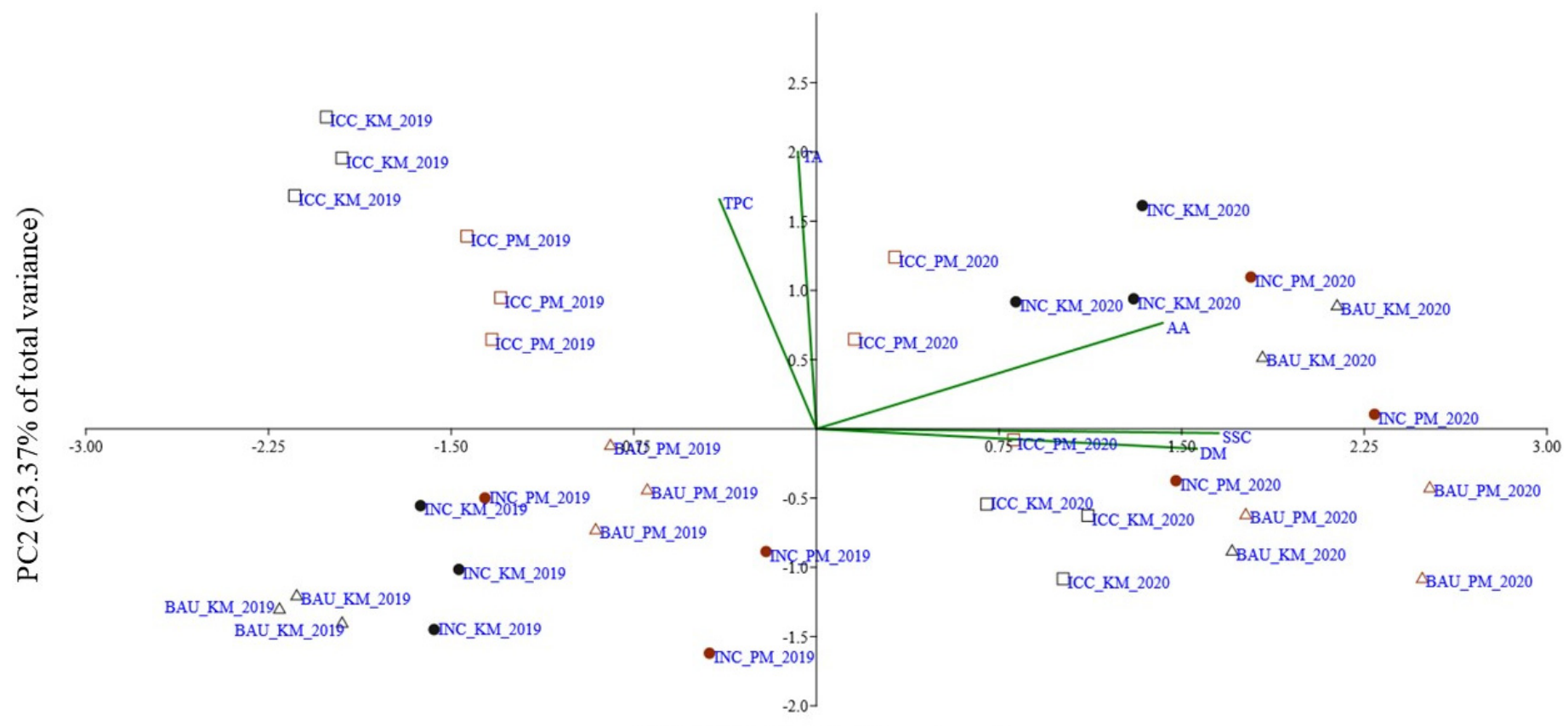

PC1 $(49.91 \%$ of total variance)

Figure 3. Biplot of Principal Component Analysis (PCA) performed on the two apricot cultivars (i.e., Kioto* KM and Pieve* PM), with three different system management systems (Business As Usual = BAU Innovative diversified system with Natural cover and Compost use = INC; Innovative diversified system with introduced Cover and Compost use = ICC), during 2019-2020. Legend: SSC = solid soluble content; TA = titratable acidity; DM = dry matter, TPC = total phenolic content; $\mathrm{AA}=$ antioxidant activity.

\section{Discussion}

Apricot is one of the most important fruit species grown in the world for its satisfying energetic, dietetic, nutritional and nutraceutical values, linked to different chemical compounds which give a good appearance and a high consumer acceptability [25]. In this study, the characterization of two cultivars (Kioto* and Pieve*), aiming to evaluate the effects of different organic system managements, was carried out through chemical and statistical analyses of nutraceutical and pomological traits. In addition, the two-year study, coupled with chemometric processing, allowed evaluating the effects of weather variability on qualitative traits. Our results confirmed the strong relationship between fruit quality parameters and climate and genotypes, as reported by several authors [5,25-27]. In accordance with Leccese et al. [5], our study highlighted no significant differences of flesh and skin CIELab coordinates respect to monitored years and management systems. Indeed, in order to reduce the effects of different fruit maturation on qualitative parameters, fruit were selected at similar ripening stage based on homogeneous CIELab coordinates, as suggested by Bureau et al. [28] Contrary to what reported by Leccese et al. [5] and Bartolini et al. [29], the restricted variation recorded between the two tested cultivars for qualitative parameters, such as fruit fresh weight, titratable acidity TPC and AA, could be due to the discrete genetic proximity of Kioto* and Pieve*, as reported by Salazar et al. [30]. At harvest, both cultivars showed a SSC content higher than

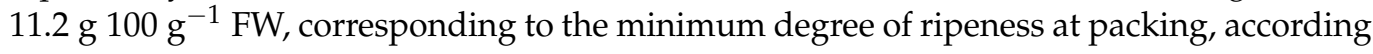


to the mean value below the threshold indicated by the European Commission about apricots marketing (Commission Regulation (EC) n. 112/2001) [31]. For what concerns the SSC, on both cultivars we found higher values than the means reported in literature [32-34], reasonably due to the specific genotypes and climatic/management conditions of the trials. Moreover, the SSC/TA ratio was also evaluated, because it is a good indicator of ripening and contributes to the overall organoleptic quality: high values represent a high perception of sweetness for consumer [35]. On average, higher SSC/TA values than the maximum value reported by Amoriello et al. [36] for seven widely spread cultivars were observed. The high recorded dry matter content of both tested cultivars suggested their suitability for processing, especially for drying [26].

According to Bartolini et al. [37] and Tarantino et al. [38] reporting high dependence of SSC, DM, TPC and AA accumulations in apricot fruits on the climatic conditions (air temperature and rainfall rate, in particular), our result confirmed the strong effect of the years and, thus, weather variability on qualitative parameters, with the exception weight, colors and TA. Actually, it is well known how the climate and weather variability holds an important role on the qualitative and nutritional parameters of vegetables and fruits [37-40]. Bartolini et al. [37] reported a key role of water availability on fruit quality traits, highlighting a lowest SSC and DM values and a higher TA content on fruits grown and ripened during warm-wet spring season. Similar results were observed in our study, confirming low SSC and high TA values during 2019-2020 (characterized by less abundant rainfall). Consequently, also the SSC/TA ratio was strongly influenced by water availability. Furthermore, beside water availability, light intensity and air temperature are related to the antioxidant activity in different fruit species [41]. Contrary to the results of Bartolini et al. [36], in our organic trial apricot fruits had the lowest antioxidant levels and the highest TPC values if high amounts of rainfall occurred during the growing period. This apparent discrepancy could be due to the measure methodology used for the antioxidant activity evaluation (Ferric Antioxidant Power FRAP, 2,2'-Azino-bis(3-ethylbenzothiazoline-6-sulfonic acid) diammonium salt Radical Scavenging Assay ABTS, DPPH etc.), that strongly influenced the evaluation and could represent a limit [42]. Conversely, our results were in accordance with Sahamishiirazi et al. [43], reporting the highest TPC level when the highest humidity occurred during fruit growing period. In detail, high humidity could influence the transpiration and photosynthetic activities and consequently results in high TPC synthesis [43]. Sahamishirazi et al. [43] and Solovchenko and Schmitz-Eiberger [44] also showed that the antioxidant biosynthesis depends on temperature and spectral properties of light. High solar radiation and temperatures could contribute to reach high AA values, as it happened during the harvest year 2019-2020.

The management system adopted on fruits trees could strongly influence the quality parameters [45]. In particular, the different organic management options for orchards might impact the biogeochemical processes and soil properties (e.g., $\mathrm{pH}$, soil biotic activity, organic matter mineralization) dealing with the function of supplying nutrient to the plant [45]. Different intake of nutrients, such as phosphorus and nitrogen, could significantly affect the biosynthesis of fruits SSC and TPC, consequently causing a strong variation of AA [46,47]. Many studies showed an increase of TPC and SSC content when lower nitrogen availability due to the slow-release property of organic nutrient input occurs $[46,47]$. We observed similar trend in our study: the TPC values for INC system increased during 2020 when soil total nitrogen decreased, as showed in Figure 1. Beside the role of tillage, this effect showed not being related to the fertilizer, with similar trend for BAU and ICC (Figure 1). This result could be related to the low C:N ratio (Table 1) of the used municipal waste compost, leading to a fast $\mathrm{N}$ release into the soil, similarly to the commercial fertilizer. However, the different compounds biosynthesis could be due to upon activation of defense mechanisms which could favor the accumulation of these compounds [47]. Moreover, there is evidence that differences in fertilization regimens (different $\mathrm{N}$ input) are responsible for higher TPC content in organic harvests [48]. The reduction of plant nitrogen availability could be due to also other factors such as soil temperature and rainfall amount, which 
affect the transformation of nitrogen into forms that can be assimilated by the plant or the washout. In our study, the higher rainfall associated with low soil temperature that occurred during 2019 could have led to a loss in TOC as reported in Figure 1, in agreement with Nie et al. [49]. Consequently, apricot fruit qualitative parameters differed among the organic management systems in the two harvest years. Nowadays, little is known about the possible impact of conservation agriculture on the content of fruits phytochemicals in relation to the different organic management system. However, our results highlighted a synergic effects of weather conditions and soil management. No tillage management coupled with municipal waste compost fertilization and natural cover in environments with low precipitation and high solar radiation, had particular effect on SSC, TA and DM parameters. Unlike our results, Massantini et al. [50] reported no effect of tillage on tomato SSC and TA values and significant differences for chemical traits when different cover crop was used. Furthermore, high TPC and antioxidant content in apple fruits were observed by Ceccanti et al. [51] when soil was no tilled. On the contrary, we found the highest values when soil tillage was used coupled with municipal waste compost fertilization and cover crop mixtures. According to several studies, high levels of health promoting phytochemicals in fruit productions could be linked to several environmental conditions, such as greater plant stress, peculiar rhizosphere microbial communities, and/or lower available nitrogen $[3,16,21,46,51,52]$. Actually, in our study the introduction of cover crops in the ICC system could have resulted in a short-term shortage of nutrients' availability in the soil for the fruit crop, since competition for resources during the cover crop growing period (November-April) could have occurred $[53,54]$. The utilization of Italian ryegrass or oat (highly competitive cereals [55]), in the cover crop mixture, beside the provision of ecosystems services such as the control of the spontaneous flora development, organic matter inputs, soil protection and nutrient leaching prevention during the rainiest period, could have interfered with the apricot plants, stimulating the defense response of the crop, finally benefiting the fruit phenolic content. This result is supported by the mean coverage of the cover crop evaluated at termination (70.8\%, standard deviation 20.6) and confirms the close linkage between the system management and fruit product quality and its nutritional value. It also suggests the need for careful management of complexity (e.g., cover crop species choice in the mixtures composition) to drive system towards mitigation of potential disservices (i.e., potential production loss due to competition with cover crops) in favor of services (i.e., increase of TPC content of the fruits).

\section{Conclusions}

This paper provides information regarding the effects of different organic management systems during two-year trials on fruit quality traits (SSC, TA, DM, and SSC/TA) and phytochemical content (TPC and AA) of two widely spread apricot cultivars. Multivariate analysis revealed a greater influence of harvest year on SSC and DM, whereas TPC and AA appeared to be mostly affected by the system management.

Nowadays, the strategy to increase soil fertility, the related fruit quality while preserving the environment is based on the use of renewable resources (e.g., compost), recycle of key compounds (nitrogen, phosphorus potassium or organic matter) and reduced tillage that may minimize the environmental hazards and maximize the ecological benefits. In this context, INC management turned out to be really interesting in regard to SSC, TA and DM parameters, especially for environments with low precipitation and high solar radiation. As well-known, apricots with high SSC and DM are commonly used for processing, such as juice, dried fruit or jam. As regards antioxidant activity, ICC management showed the highest values, especially for environment with high precipitation. In this context, PCA was a useful tool to evaluate simultaneously the pomological and nutraceutical parameters respect to the cultivars, harvest years and organic management systems. This information might be useful for farmers to choose the best organic system management in relation to the long-term meteorological data, in order to obtain fruits with high pomological and nutraceutical potential. 
Supplementary Materials: The following are available online at https://www.mdpi.com/article/10 .3390/agronomy11091791/s1, Table S1: Means data, standard deviation (SD), minimum (Min) and maximum (Max) value of fruits weight and color coordinates (CIElab) divided by cultivar (Kioto* KM and Pieve* PM), agronomic treatment (Business As Usual - BAU; Innovative diversified system with Natural cover and Compost use-ICC; Innovative diversified system with introduced Cover and Compost use-INC) and years. Table S2: Means data, standard deviation (SD), minimum (Min) and maximum (Max) value of SSC:TA divided by cultivar (Kioto* KM and Pieve* PM), agronomic treatment (Business As Usual-BAU; Innovative diversified system with Natural cover and Compost use-ICC; Innovative diversified system with introduced Cover and Compost use-INC) and years.

Author Contributions: R.C. (Roberto Ciccoritti): Conceptualization, Methodology, Software, Validation, Formal analysis, Investigation, Data Curation, Writing-Original Draft, Writing-Review \& Editing; R.C. (Roberto Ciorba): Methodology, Formal analysis; F.M.: Methodology, Formal analysis; M.C.: Conceptualization, Methodology, Investigation, Data Curation, Writing-Original Draft, Writing-Review \& Editing; T.A.: Conceptualization, Software, Validation, Data Curation, WritingOriginal Draft, Writing-Review \& Editing; C.C.: Conceptualization, Methodology, Formal analysis, Investigation, Data Curation, Writing-Original Draft, Writing-Review \& Editing; E.T.: Conceptualization, Methodology, Formal analysis, Investigation, Data Curation, Writing-Original Draft, Writing-Review \& Editing; D.C.: Conceptualization, Investigation, Resources, Data Curation, Supervision, Writing-Original Draft, Project administration, Funding acquisition. All authors have read and agreed to the published version of the manuscript.

Funding: This research was supported by Italian Ministry of Agricultural, Food and Forestry Policies (MIPAAF) BIOPAC Project DM 22/12/2016 n. 95785.

Institutional Review Board Statement: Not applicable.

Informed Consent Statement: Not applicable.

Data Availability Statement: Not applicable.

Acknowledgments: Authors thank CREA-OFA Technical Staff for their contribution and in particular Stefano Trotta of CREA AA for the soil analyses.

Conflicts of Interest: No potential conflict of interest was reported by the authors.

\section{References}

1. FAOSTAT. Food and Agriculture Organization Statistical Databases. 2019. Available online: http://faostat.fao.org (accessed on 25 June 2021).

2. Leccese, A.; Bartolini, S.; Viti, R. Total antioxidant capacity and phenolics content in apricot fruits. Int. J. Fruit Sci. 2007, 7, 3-16. [CrossRef]

3. Leccese, A.; Bureau, S.; Reich, M.; Renard, M.C.; Audergon, J.M.; Mennone, C.; Bartolini, S.; Viti, R. Pomological and nutraceutical properties in apricot fruit: Cultivation systems and cold storage fruit management. Plant Food. Hum. Nutr. 2010, 65, 112-120. [CrossRef]

4. Leccese, A.; Bartolini, S.; Viti, R. From genotype to apricot fruit quality: The antioxidant properties contribution. Plant Food. Hum. Nutr. 2012, 67, 317-325. [CrossRef]

5. Hegedüs, A.; Engel, R.; Abrankó, L.; Balogh, E.; Blázovics, A.; Hermán, R.; Halász, J.; Ercisli, S.; Pedryc, A.; Stefanovits-Bányai, É. Antioxidant and antiradical capacities in apricot (Prunus armeniaca L.) fruits: Variations from genotypes, years, and analytical methods. J. Food Sci. 2010, 75, C722-C730. [CrossRef]

6. Hegedüs, A.; Pfeiffer, P.; Papp, N.; Abrankó, L.; Blázovics, A.; Pedryc, A.; Stefanovits-Bányai, E. Accumulation of antioxidants in apricot fruit through ripening: Characterization of a genotype with enhanced functional properties. Biol. Res. 2011, 44, 339-344. [CrossRef]

7. Schmitzer, V.; Slatnar, A.; Mikulic-Petkovsek, M.; Veberic, R.; Krska, B.; Stampar, F. Comparative study of primary and secondary metabolites in apricot (Prunus armeniaca L.) cultivars. J. Sci. Food Agric. 2011, 91, 860-866. [CrossRef]

8. Ruiz, D.; Egea, J.; Tomás-Barberán, F.A.; Gil, M.I. Carotenoids from new apricot (Prunus armeniaca L.) varieties and their relationship with flesh and skin color. J. Agric. Food Chem. 2005, 53, 6368-6374. [CrossRef]

9. Amoriello, T.; Ciccoritti, R.; Paliotta, M.; Carbone, K. Classification and prediction of early-to-late ripening apricot quality using spectroscopic techniques combined with chemometric tools. Sci. Hortic. 2018, 240, 310-317. [CrossRef]

10. Ciaccia, C.; Ceccarelli, D.; Antichi, D.; Canali, S. Long-term experiments on agroecology and organic farming: The Italian long-term experiment network. In Long-Term Farming Systems Research; Bhullar, G., Riar, A., Eds.; Academic Press: Cambridge, MA, USA; Elsevier: London, UK, 2020; pp. 183-196. 
11. Milošević, T.; Milošević, N.; Glišić, I. Tree growth, yield, fruit quality attributes and leaf nutrient content of ‘Roxana'apricot as influenced by natural zeolite, organic and inorganic fertilisers. Sci. Hortic. 2013, 156, 131-139. [CrossRef]

12. Stojanov, D.; Milošević, T.; Mašković, P.; Milošević, N.; Glišić, I.; Paunović, G. Influence of organic, organo-mineral and mineral fertilisers on cane traits, productivity and berry quality of red raspberry (Rubus idaeus L.). Sci. Hortic. 2019, 252, 370-378. [CrossRef]

13. Colazo, J.C.; Buschiazzo, D. The impact of agriculture on soil texture due to wind erosion. Land Degrad. Dev. 2015, 26, 62-70. [CrossRef]

14. Novara, A.; Rühl, J.; La Mantia, T.; Gristina, L.; La Bella, S.; Tuttolomondo, T. Litter contribution to soil organic carbon in the processes of agriculture abandon. Solid Earth 2015, 6, 425-432. [CrossRef]

15. Yan, Y.; Cai, L. Multi-scale anthropogenic driving forces of Karst Rocky desertification in Southwest China. Land Degrad. Dev. 2015, 26, 193-200. [CrossRef]

16. Morugán-Coronado, A.; Linares, C.; Gómez-López, M.D.; Faz, Á.; Zornoza, R. The impact of intercropping, tillage and fertilizer type on soil and crop yield in fruit orchards under Mediterranean conditions: A meta-analysis of field studies. Agric. Syst. 2020, 178, 102736. [CrossRef]

17. European Commission (EC). From Farm to Fork: Our Food, Our Health, Our Planet, Our Future. The European Green Deal. Factsheet. 2020. Available online: https://ec.europa.eu/commission/presscorner/detail/en/fs_20_908 (accessed on 25 June 2021).

18. European Commission (EC). Bringing Nature Back into Our Lives. EU 2030 Biodiversity Strategy. Factsheet. 2020. Available online: https:/ / ec.europa.eu/commission/presscorner/detail/en/fs_20_906 (accessed on 25 June 2021).

19. Levidow, L.; Pimbert, M.; Vanloqueren, G. Agroecological Research: Conforming or Transforming the Dominant Agro-Food Regime? Agroecol. Sust. Food 2014, 38, 1127-1155. [CrossRef]

20. Sayara, T.; Basheer-Salimia, R.; Hawamde, F.; Sánchez, A. Recycling of Organic Wastes through Composting: Process Performance and Compost Application in Agriculture. Agronomy 2020, 10, 1838. [CrossRef]

21. Demir, Z.; Tursun, N.; Issı1k, D. Effects of different cover crops on soil quality parameters and yield in an apricot orchard. Int. J. Agric. Biol. 2019, 21, 399-408.

22. Brevik, E.C. Soil Health and Productivity. In Soils, Plant Growth and Crop Production-Volume 1; Brevik, E.C., Verheye, W., Eds.; Encyclopedia of Life Support Systems (EOLSS); EOLSS Publishers: Oxford, UK, 2009. Available online: http:/ / www.eolss.net (accessed on 15 May 2021).

23. Ciaccia, C.; Di Pierro, M.; Testani, E.; Roccuzzo, G.; Cutuli, M.; Ceccarelli, D. Participatory Research towards Food System Redesign: Italian Case Study and Perspectives. Sustainability 2019, 11, 7138. [CrossRef]

24. Ceccarelli, D.; Antonucci, F.; Costa, C.; Talento, C.; Ciccoritti, R. An artificial class modelling approach to identify the most largely diffused cultivars of sweet cherry (Prunus avium L.) in Italy. Food Chem. 2020, 333, 127515. [CrossRef]

25. Ruiz, D.; Egea, J. Phenotypic diversity and relationships of fruit quality traits in apricot (Prunus armeniaca L.) germplasm. Euphytica 2008, 163, 143-158. [CrossRef]

26. Carbone, K.; Ciccoritti, R.; Paliotta, M.; Rosato, T.; Terlizzi, M.; Cipriani, G. Chemometric classification of early-ripening apricot (Prunus armeniaca, L.) germplasm based on quality traits, biochemical profiling and in vitro biological activity. Sci. Hortic. 2018, 227, 187-195. [CrossRef]

27. Pérez-Sarmiento, F.; Mirás-Avalos, J.M.; Alcobendas, R.; Alarcón, J.J.; Mounzer, O.; Nicolás, E. Effects of regulated deficit irrigation on physiology, yield and fruit quality in apricot trees under Mediterranean conditions. Span. J. Agric. Res. 2016, $14,1205$. [CrossRef]

28. Bureau, S.; Renard, C.M.; Reich, M.; Ginies, C.; Audergon, J.M. Change in anthocyanin concentrations in red apricot fruits during ripening. LWT-Food Sci. Technol. 2009, 42, 372-377. [CrossRef]

29. Bartolini, S.; Leccese, A.; Remorini, D.; Iacona, C.; Viti, R. Quality and antioxidant traits of organic apricots (Prunus armeniaca L.) at harvest and after storage. J. Sci. Food Agric. 2019, 83, 12-17. [CrossRef]

30. Salazar, J.A.; Rubio, M.; Ruiz, D.; Tartarini, S.; Martínez-Gómez, P.; Dondini, L. SNP development for genetic diversity analysis in apricot. Tree Genet. Genomes 2015, 11, 15. [CrossRef]

31. European Commission. 2001 European Commission Commission Regulation (EC) No. 112/2001 of 28 Amending Annex II (Technical Regulations, Standards, Testing and Certification) to the EEA Agreement. Off. J. Eur. Communities 2001, L92, 9-10. Available online: https: / / eur-lex.europa.eu/legal-content (accessed on 25 June 2021).

32. Kafkaletou, M.; Kalantzis, I.; Karantzi, A.; Christopoulos, M.V.; Tsantili, E. Phytochemical characterization in traditional and modern apricot (Prunus armeniaca L.) cultivars-Nutritional value and its relation to origin. Sci. Hortic. 2019, 253, 195-202. [CrossRef]

33. Milatović, D.; Đurović, D.; Zec, G. Evaluation of french apricot cultivars in the region of Belgrade. In IV International Symposium Agrosym 2013, Jahorina, Bosnia and Herzegovina, 3-6 October 2013; Faculty of Agriculture, University of East Sarajevo, Republic of Srpska, Bosnia and Herzegovina: Lukavica, Republika Srpska, 2013; pp. 196-201.

34. Gurrieri, F.; Audergon, J.M.; Albagnac, G.; Reich, M. Soluble sugars and carboxylic acids in ripe apricot fruit as parameters for distinguishing different cultivars. Euphytica 2001, 117, 183-189. [CrossRef] 
35. Crisosto, C.H.; Crisosto, G.M. Relationship between ripe soluble solids concentration (RSSC) and consumer acceptance of high and low acid melting flesh peach and nectarine (Prunus persica (L.) Batsch) cultivars. Postharvest Biol. Technol. 2005, 38, $239-246$. [CrossRef]

36. Amoriello, T.; Ciccoritti, R.; Carbone, K. Vibrational spectroscopy as a green technology for predicting nutraceutical properties and antiradical potential of early-to-late apricot genotypes. Postharvest Biol. Technol. 2019, 155, 156-166. [CrossRef]

37. Bartolini, S.; Leccese, A.; Viti, R. Quality and antioxidant properties of apricot fruits at ready-to-eat: Influence of the weather conditions under Mediterranean coastal area. J. Food Process. Technol. 2015, 7, 1-6.

38. Tarantino, A.; Lops, F.; Disciglio, G.; Lopriore, G. Effects of plant biostimulants on fruit set, growth, yield and fruit quality attributes of 'Orange rubis ${ }^{\circledR}$ 'apricot (Prunus armeniaca L.) cultivar in two consecutive years. Sci. Hortic. 2018, 239, 26-34. [CrossRef]

39. Ceccarelli, D.; Antonucci, F.; Talento, C.; Ciccoritti, R. Chemical characterization in the selection of Italian autochthonous genotypes of plum. Sci. Hortic. 2021, 281, 109922. [CrossRef]

40. Ceccarelli, D.; Antonucci, F.; Talento, C.; Costa, C.; Caboni, E.; Ciccoritti, R. Can environment and genotype influence sweet cherry qualitative parameters? Plant Biosyst. 2021, 1-9. [CrossRef]

41. Lee, S.K.; Kader, A.A. Preharvest and postharvest factors influencing vitamin C content of horticultural crops. Postharv. Biol. Technol. 2000, 20, 207-220. [CrossRef]

42. Frankel, E.N.; Meyer, A.S. The problems of using one-dimensional methods to evaluate multifunctional food and biological antioxidants. J. Sci. Food Agric. 2000, 80, 1925-1941. [CrossRef]

43. Sahamishirazi, S.; Moehring, J.; Claupein, W.; Graeff-Hoenninger, S. Quality assessment of 178 cultivars of plum regarding phenolic, anthocyanin and sugar content. Food Chem. 2017, 214, 694-701. [CrossRef]

44. Solovchenko, A.; Schmitz-Eiberger, M. Significance of skin flavonoids for UV-B-protection in apple fruits. J. Exp. Bot. 2003, 54, 1977-1984. [CrossRef]

45. Montanaro, G.; Xiloyannis, C.; Nuzzo, V.; Dichio, B. Orchard management, soil organic carbon and ecosystem services in Mediterranean fruit tree crops. Sci. Hortic. 2017, 217, 92-101. [CrossRef]

46. Cuquel, F.L.; Motta, A.C.V.; Tutida, I.; Mio, L.L.M.D. Nitrogen and potassium fertilization affecting the plum postharvest quality. Rev. Bras. Frutic. 2011, 33, 328-336. [CrossRef]

47. Winter, C.K.; Davis, S.F. Organic foods. J. Food Sci. 2006, 71, 117-124. [CrossRef]

48. Stewart, A.J.; Chapman, W.; Jenkins, G.I.; Graham, I.; Martin, T.; Crozier, A. The effect of nitrogen and phosphorus deficiency on flavonol accumulation in plant tissues. Plant Cell Environ. 2001, 24, 1189-1197. [CrossRef]

49. Nie, X.; Li, Z.; Huang, J.; Huang, B.; Zhang, Y.; Ma, W.; Hu, Y.; Zeng, G. Soil organic carbon loss and selective transportation under field simulated rainfall events. PLoS ONE 2014, 9, 105927. [CrossRef]

50. Massantini, R.; Radicetti, E.; Frangipane, M.T.; Campiglia, E. Quality of Tomato (Solanum lycopersicum L.) Changes under Different Cover Crops, Soil Tillage and Nitrogen Fertilization Management. Agriculture 2021, 11, 106. [CrossRef]

51. Ceccanti, C.; Landi, M.; Antichi, D.; Guidi, L.; Manfrini, L.; Monti, M.; Tosti, G.; Frasconi, C. Bioactive Properties of fruits and leafy vegetables managed with integrated, organic, and organic no-tillage practices in the Mediterranean area: A two-year rotation experiment. Agronomy 2020, 10, 841. [CrossRef]

52. Reeve, J.R.; Hoagland, L.A.; Villalba, J.J.; Carr, P.M.; Atucha, A.; Cambardella, C.; Davis, D.R.; Delate, K. Organic farming, soil health, and food quality: Considering possible links. Adv. Agron. 2016, 137, 319-367.

53. Rodrigues, M.Â.; Arrobas, M. Cover cropping for increasing fruit production and farming sustainability. Fruit Crops 2020, $279-295$.

54. Rodrigues, M.A.; Lopes, J.I.; Pavao, F.M.; Cabanas, J.E.; Arrobas, M. Effect of soil management on olive yield and nutritional status of trees in rainfed orchards. Commun. Soil. Sci. Plant Anal. 2011, 42, 993-1007. [CrossRef]

55. Sarrantonio, M.; Gallandt, E. The role of cover crops in North American cropping systems. J. Crop Prod. 2003, 8, 53-74. [CrossRef] 